\title{
Design and Analysis of Intake Port of Diesel Engine for Target Value of Swirl
}

\author{
S.K. Sabale*, S.B. Sanap \\ Department of Mechanical Engineering, Sinhgad College of Engineering, Pune, India \\ *Corresponding author: sonalisabale.scoe@gmail.com
}

Received September 21, 2013; Revised October 15, 2013; Accepted October 20, 2013

\begin{abstract}
The mutual desire for higher fuel economy and greater performance along with stringent emission regulations set by the government for diesel engines necessitates enhanced air-fuel mixing for proper combustion. The design of intake port plays a major role in an engine design, development and optimization, as it controls the power developed, fuel consumed and exhaust emissions from the engine. The effects of different geometrical parameters of helical port on swirl performance were studied. A methodology is proposed for the design of helical inlet port of diesel engine in order to achieve target value of 1.8 swirl number. The computational fluid dynamics approach is used for analysis of intake port performance. The port performance of prototype flow box was analyzed experimentally on a steady flow rig. The observed mean swirl number and flow capacity values satisfy the requirements.
\end{abstract}

Keywords: CFD, experimental testing, helical port, helix, swirl

Cite This Article: S.K.Sabale, and S.B.Sanap, "Design and Analysis of Intake Port of Diesel Engine for Target Value of Swirl." American Journal of Mechanical Engineering 1, no. 5 (2013): 138-142. doi: 10.12691/ajme-1-5-6.

\section{Introduction}

An important step towards the development of aninternal combustion engines is the optimization of the inflow through intake ports since the charge movement generated by the intake flow considerably influences the quality of mixture and combustion especially in diesel engines. Combustion chamber flow field characteristics atthe time of fuel injection and subsequent interactions with fuel sprays and combustion phenomena are dominant parameters for the engine performance and exhaust emissions levels in a direct injection diesel engine. Exact matching of the engine, fuel injection parameters, bowl shape, compression ratio and scavenging characteristics as well as exhaust gas recirculation are important considerations in a new engine design. The in-cylinder flow field is largely determined by the swirl and tumble motion during the intake stroke and the squish flow into and out of a piston bowl. Since the nature of the swirling flow in an engine under operation is extremely difficult to determine, steady flow tests are often used to characterize the swirl and discharge coefficient. So that it becomes important steps in a new engine design to comeup with the geometrical shape of an intake port or valve that produces the optimum swirl ratio [1].

The researches [2-8] have shown that helical type intake-port will be ideal for the engine with nominal injection pressure value less than 800 bar and having single orifice injector.

The recent experiments and computations have indicated that the induction generated turbulence, independent of its initial magnitude decays by the time of ignition to levels determined by the engine speed. Therefore, it is desirable for the bulk in-cylinder flow to persist through compression. Hence, releasing its stored kinetic energy at convenient time for combustion to be affected. The controlling parameter is the design and orientation of intake port, in the absence of piston bowl effects. The significant portion of the combustion process takes place by diffusion of flames in a diesel engine. The air-fuel mixing controls the rate of chemical reaction and hence the heat release under this condition. The earlier studies show that the air-fuel mixing is a function of kinetic energies associated with fuel injection and air turbulence [9]. McCracken and Abraham [10] studied the effects of swirl turbulence and its interaction with fuel sprays. Khan, et. al. [10] investigated the effects of air swirl on smoke and gaseous pollutants of DI diesel engines and also the mechanisms of their formations. Thien [11] studied the in-cylinder swirl in detail and proposed a mathematical model for designing the geometry of a helical port by classical methods, and the method is an important basis to calculate the geometry of port.

\section{Development of Helical Intake Port}

The development of port for target value of swirl is achieved by analysing several ports available at Power Train Engineering (PTE) department, ARAI, Pune and the parameters that affect swirl performance.

\subsection{Calculation of Port Dimensions}


The helical port consists of three principle components,

\begin{tabular}{|c|c|}
\hline SCROLL & $\mathrm{S}, \mathrm{R}, \mathrm{W}, \boldsymbol{\beta}$ \\
\hline INLET & $\mathrm{S}, \boldsymbol{\theta}$ \\
\hline THROAT & $\mathrm{T}, \mathrm{X}, \mathrm{Y}$ \\
\hline
\end{tabular}

The influence of each geometrical parameter is examined.

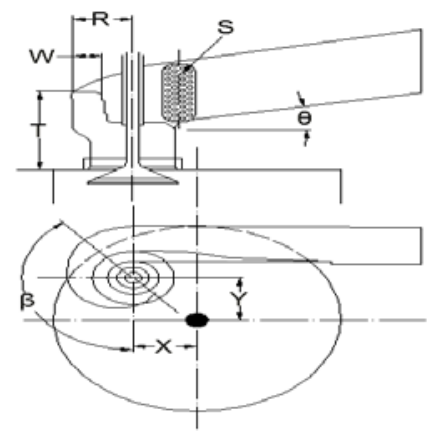

Figure 1. Geometric parameters of helical port [12]

In order to analyse effects of the intake port geometry and examine measures for making further improvements, it is essential to know the performances of the ports. Therefore 8 ports were taken for analysing data to arrive at acceptable trendline. Table 1 shows the diesel engine specifications on which the ports are employed.

Table 1. Engine Specifications

\begin{tabular}{|c|c|}
\hline Bore, $\mathrm{mm}$ & 100 \\
\hline Stroke, $\mathrm{mm}$ & 100 \\
\hline Number of cylinders & 3 \\
\hline Aspiration & Naturally Aspirated \\
\hline Application & Off highway \\
\hline
\end{tabular}

\subsection{Area Calculation of Selected Ports}

The information of different ports available at Power Train Engineering (PTE) department, ARAI, Pune is correlated in order to get a clear idea of area required for target value of swirl number. The following methodology is considered for cross-sectional area calculation of selected ports

1. Creating section planes at $15^{\circ}$ angle up to scroll angle for selected ports.

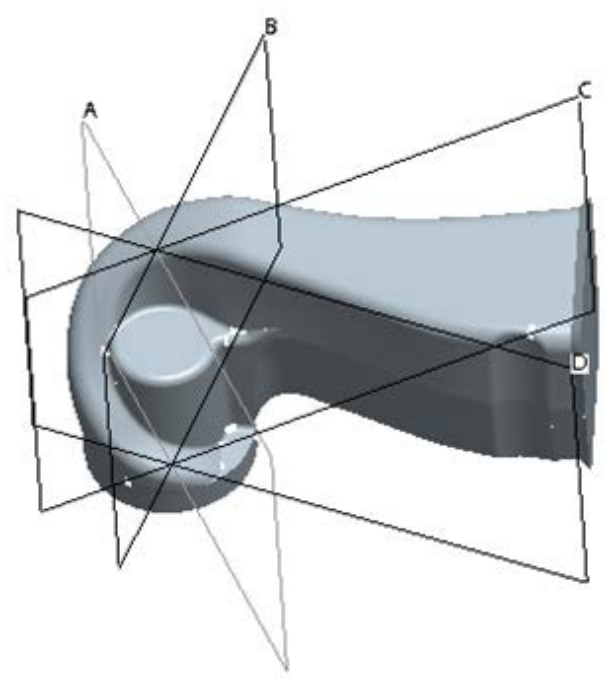

Figure 2. Section planes created in Pro-E

The Figure 2 shows section planes that are created in Pro-E.
2. Measurement of the cross-sectional area of section planes for selected ports.

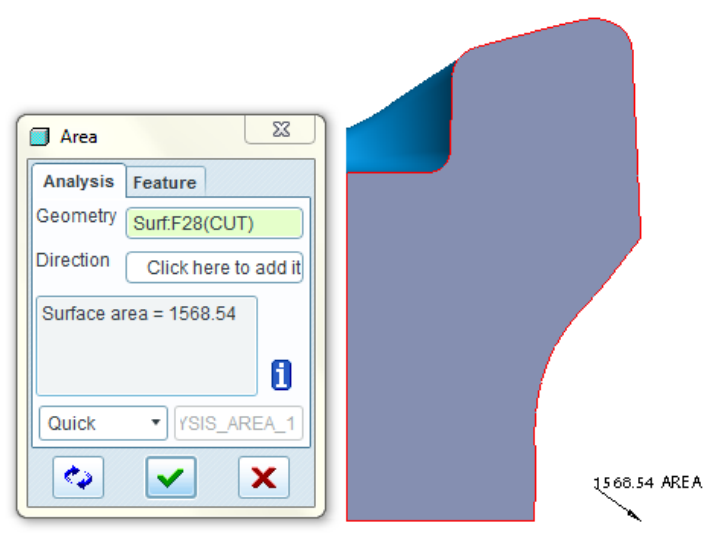

Figure 3. Measurement of cross-sectional area of section planes in Pro-E

The Figure 3 shows measurement of cross-sectional area of section planes using Pro-E. Similarly, crosssectional area of remaining section planes for selected ports is measured.

3. Creating trend line for the cross-sectional areas of section planes for selected ports. The Figure 4 is a plot of cross-sectional area $\left(\mathrm{mm}^{2}\right)$ vs. section plane angle (degree) showing the trend lines of crosssectional area of section plane for selected ports.

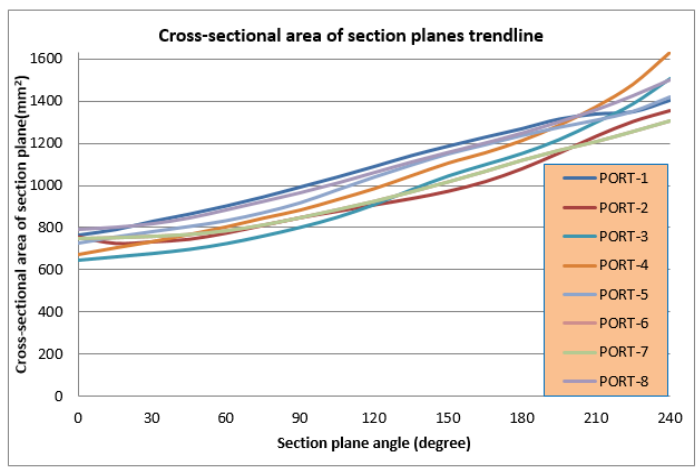

Figure 4. Port cross-sectional area of section planes trendline

\subsection{Area Calculation of Proposed Port}

The following methodology is considered for area calculation of proposed port.

1. The first cross-sectional area of proposed port where the helix begins is calculated based on the first crosssectional areas of analysed ports in order to achieve target value of swirl number. Here, the first crosssectional areas of each port are evaluated using 3D CAD Pro-E software. A trendline of swirl number vs. first cross-sectional areas of ports is drawn.

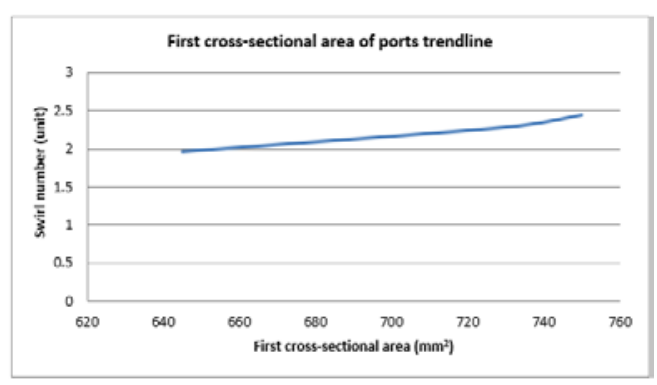

Figure 5. First cross-sectional area of ports trendline 
The Figure 5 is a plot of swirl number (unit) vs. first cross-sectional area $\left(\mathrm{mm}^{2}\right)$ of selected ports showing the trendline of swirl number vs. first cross-sectional areas of ports.

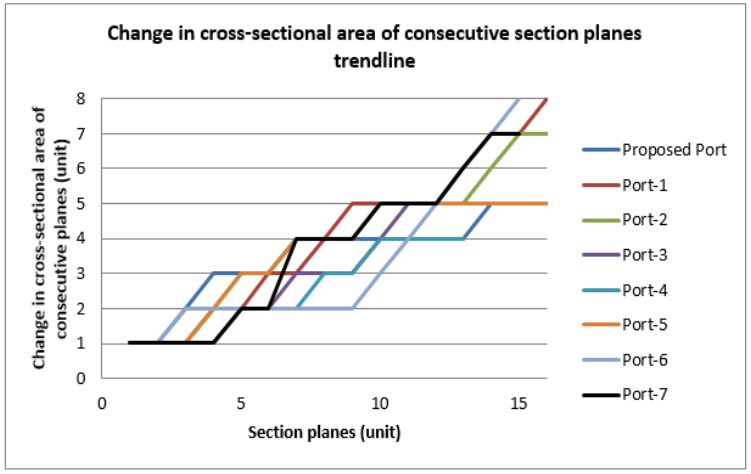

Figure 6. Change in cross-sectional area of consecutive section planes trend line

2. The cross-sectional area required at the section planes is evaluated. The difference in sectional area in consecutive section planes for each selected ports are calculated for this. Then trend lines for the crosssectional area at section planes for the selected ports are drawn. The Figure 6 is a plot of change in crosssectional area of consecutive planes (unit) vs. section planes (unit) showing the trendline of change in cross-sectional area of consecutive section planes.

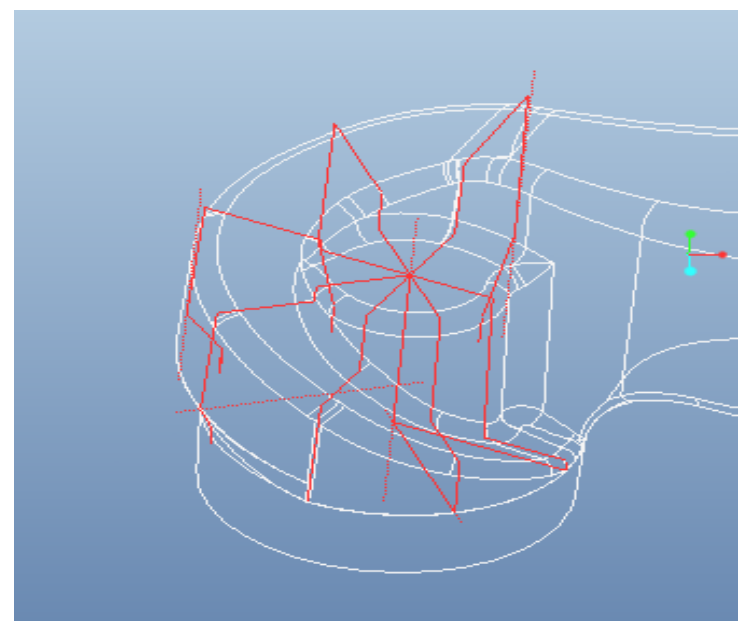

Figure 7. Profile sketches in section planes

3. The starting position of first helix angle for proposed port is decided based on port information analysed for selected ports. The first helix angle for the proposed port is determined by analysing scroll angle and starting point of helix for various ports.

4. The section plane profile sketch is determined for each section plane of proposed helical port to achieve target value of swirl number after deciding the first cross-sectional area, change in cross-sectional area of consecutive planes and first helix.The profile is selected based on necessary cross-sectional area for that sectional plane and smooth profile of port. The Figure 7 shows profile sketches in sectional planes of proposed helical port drawn in Pro-E.

5. The intake port model is created in 3D CAD Pro-E software by surface modelling. The model is finalized based on necessary cross-section areas and taking into account the packaging constraints. The Figure 8 shows proposed model of helical intake port.

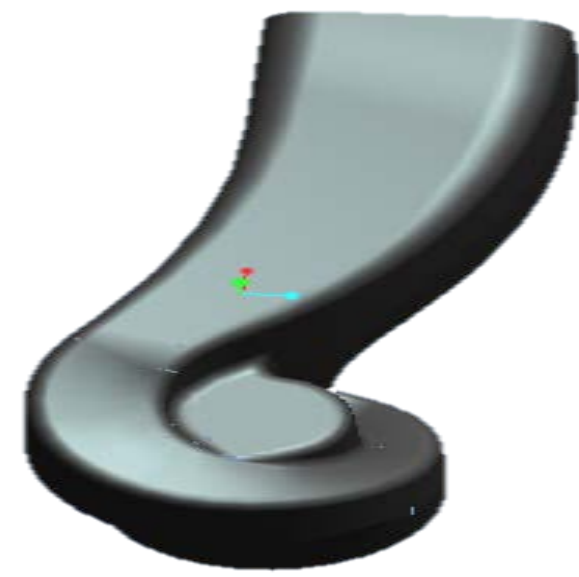

Figure 8. Proposed helical intake port

\section{Air Flow Simulation in Intake Port}

The steady state CFD analysis of proposed helical intake port is carried out for each valve lift. The engine under consideration has maximum valve lift of $11 \mathrm{~mm}$. The assembly models for each $1 \mathrm{~mm}$ valve lift are prepared in Pro-E and saved in '.stl' format.

\subsection{Steps in CFD Analysis}

The following steps are carried out in CFD air flow simulation of intake port.

1. Pre processing

2. Analysis

3. Post processing

\subsubsection{Pre-processing}

1. The three dimensional port models are imported in CFD software. '.stl' file format is most preferred format for import. After importing, port surface models are checked for data loss. Surface damages like independent regions, folded patches, manifolds, duplicate patches etc. are checked and corrected accordingly.

2. Selections like inlet, outlet, valve, seat or refinement areas are defined on surface model.

3. Edge mesh model, prepared from surface mesh consists of closed edges in boundary region.

4. The volume mesh of port is generated using Fame Advanced Hybrid Mesh (FAHM). It generates hexahedron dominated mesh, but with few tetrahedral, prism and pyramids cells in a transition layer between coarse and fine mesh.

5. A volume mesh model is needed to correct for bad cells like negative volumes, negative normal if any.

6. Refined volume mesh model is used for applying boundary conditions.

\subsubsection{Post Processing}

During post processing parameters like mass flow, flow coefficient, paddle speed, velocity, streamlines path are 
analysed. The velocity profiles and streamline path for each lift from maximum valve lift to zero valve lift are analysed to determine the swirl performance of proposed helical intake port.

\subsection{Result and Analysis}

The velocity path and streamline path, for maximum valve lift can be seen from Figure 9 and Figure 10 at a section passing through centre of valve. The velocity profile analysis at valve seat area helps in valve seat optimization and identify the critical area for flow optimization. The streamlines help in finding flow restrictions and eddy formation zones that helps in improving port flow performance by modifying area around valve. The CFD study is carried out for all valve lifts.

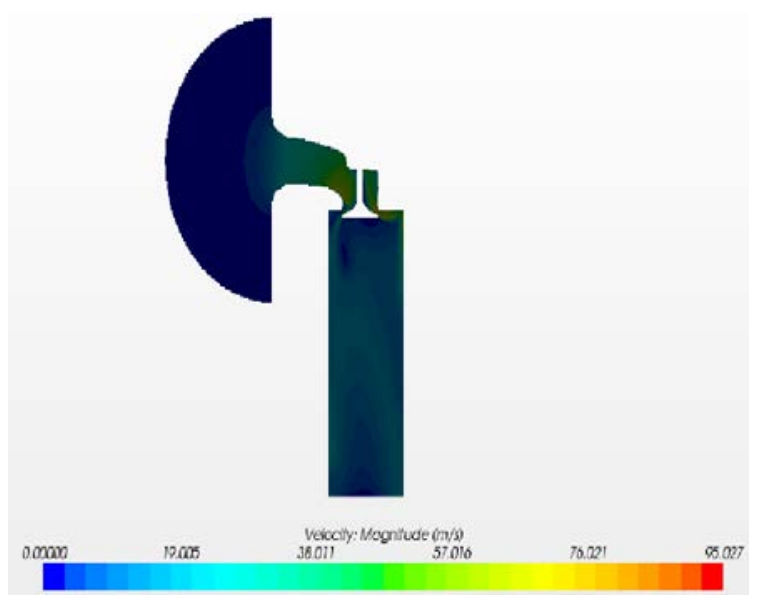

Figure 9. Velocity profile for maximum valve lift

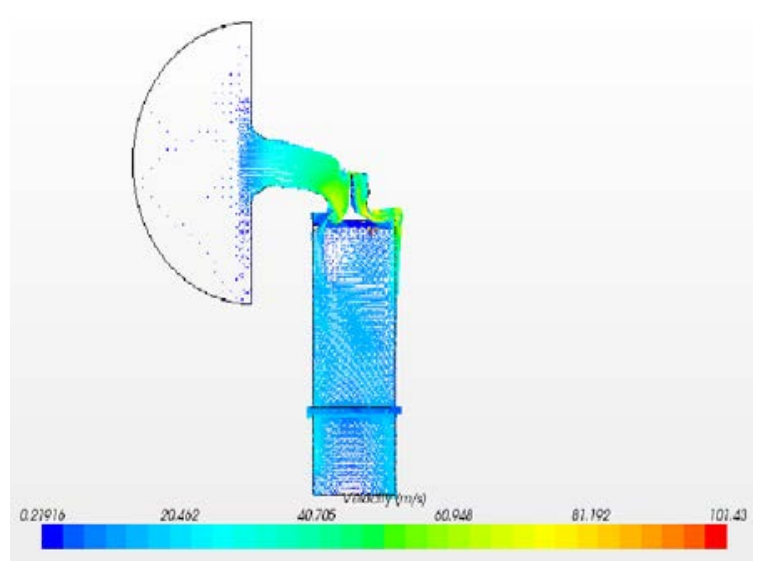

Figure 10. Streamline path for maximum valve lift

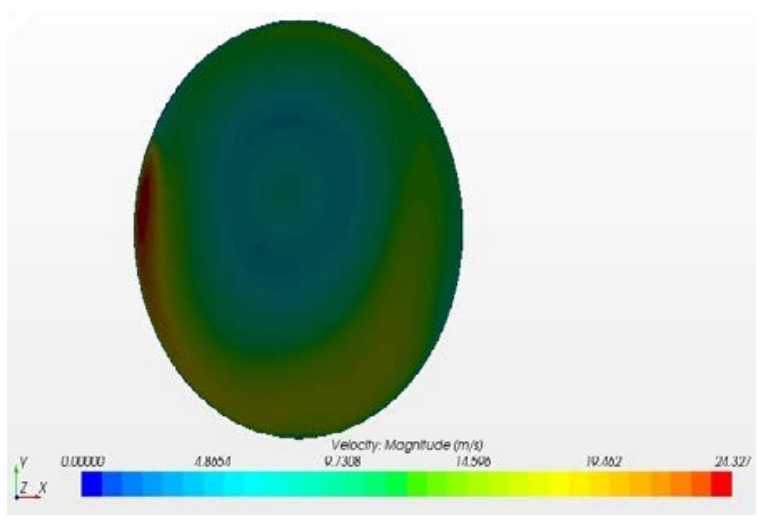

Figure 11. Velocity swirl disk
The Figure 11 shows velocity swirl disk which helps to understand swirl distribution caused by the intake port.

The CFD analysis predicts mean swirl of 1.81 .

\section{Swirl Test Rig Experiment}

The CFD simulation results obtained of paddle speed, flow coefficient, swirl number and flow for all valve lifts from maximum valve lift to zero valve lift are compared with the experimental results obtained from the testing of prototype flow-box on swirl test rig.

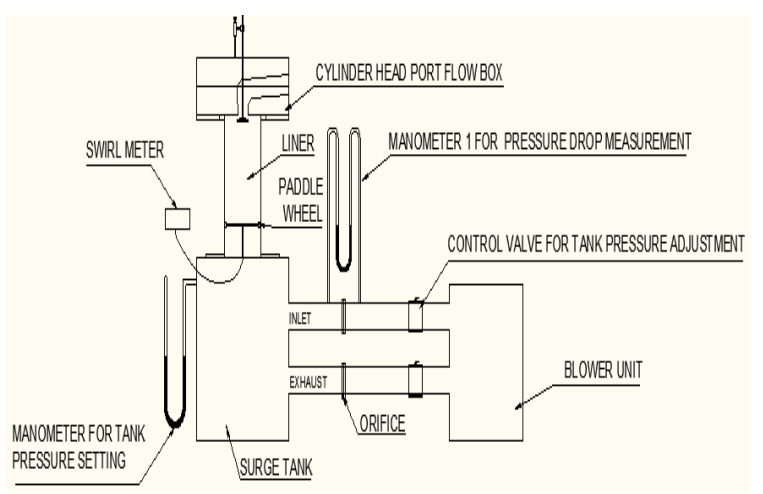

Figure 12.Setup for swirl measurement

The Figure 12 shows schematic diagram of swirl measurement setup.

Swirl ratio is evaluated from the ratio of the charge rotation speed of paddle wheel to the fictitious engine speed.

$$
\mathrm{SR}=\frac{\mathrm{n}_{\text {paddle }}}{\mathrm{n}_{\text {motor }}}
$$

Assuming the mean piston speed to be equal to mean axial velocity of the steady state flow, we get the fictitious engine speed to be

$$
\mathrm{n}_{\text {motor }}=\frac{\dot{\mathrm{m}} * 30}{\rho \mathrm{AS}}
$$

Mean swirl number is obtained by integration over the crank angle from top dead centre to bottom dead centre and considering valve lift and position speed.

$$
\mathrm{SN}=\int_{\operatorname{TDC}(\alpha=0)}^{\operatorname{BDC}(\alpha=\pi)} \frac{\mathrm{n}_{\text {paddle }}}{\mathrm{n}_{\text {motor }}}\left(\frac{\mathrm{C}(\alpha)}{\mathrm{C}_{\mathrm{m}}}\right)^{2} \mathrm{~d} \alpha
$$

Ratio between actual speed and mean piston speed

$$
\frac{C(\alpha)}{C_{m}}=\frac{\pi}{2}\left(\frac{1+\lambda \cos \alpha}{\sqrt{1-\lambda^{2} \sin ^{2} \alpha}}\right) \sin \alpha
$$

\section{Comparison}

The results obtained by CFD analysis are compared with those obtained experimentally.

\subsection{Paddle Speed}

The Figure 13 is a plot of paddle wheel speed (RPM) vs. valve lift (mm) showing the comparison of CFD and swirl test rig results of paddle wheel speed. 


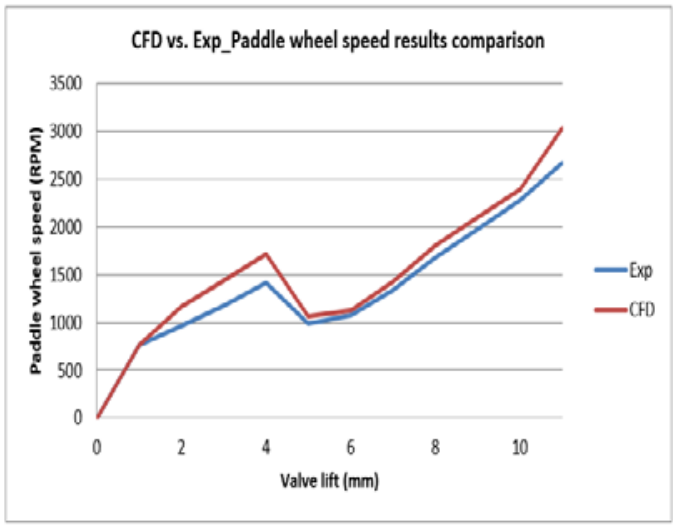

Figure 13. Paddle wheel speed results comparison

It is observed that the deviation in CFD simulation and swirl test rig results of paddle wheel is high at low lift (i.e. below $4 \mathrm{~mm}$ ) and high tank pressure (i.e. $600 \mathrm{~mm}$ of water) below atmosphere. Practically, there exists a slip between paddle wheel carrying shaft and its corresponding bearing. This is not taken into consideration during CFD analysis. This slip will be significant at high tank pressure and hence percentage error is high.

\subsection{Flow}

The CFD simulation and swirl test rig results of flow shows good correlation. The Figure 14 is a plot of flow $(\mathrm{m} / \mathrm{s})$ vs. valve lift $(\mathrm{mm})$ showing the comparison of CFD and swirl test rig results of flow. At low lifts, the error between experimental result and CFD result is maximum since the gap between valve and valve seat is small and only few cells are available for computations. It is recommended to have at least two rows at regions of small gaps.

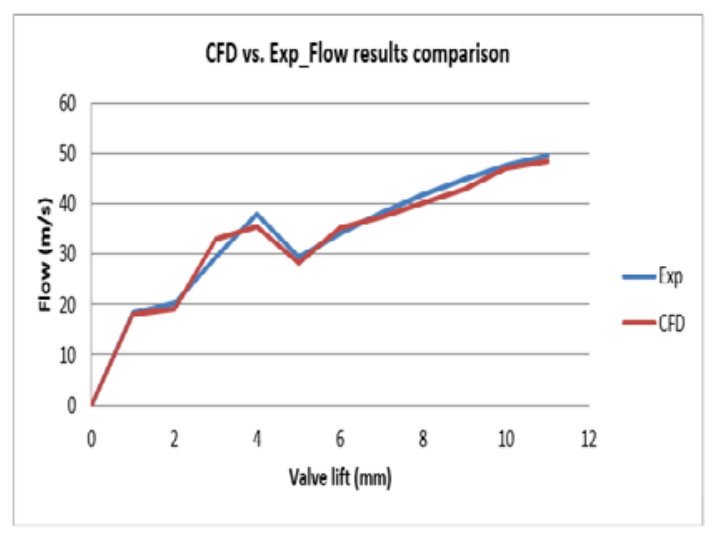

Figure 14. Flow results comparison

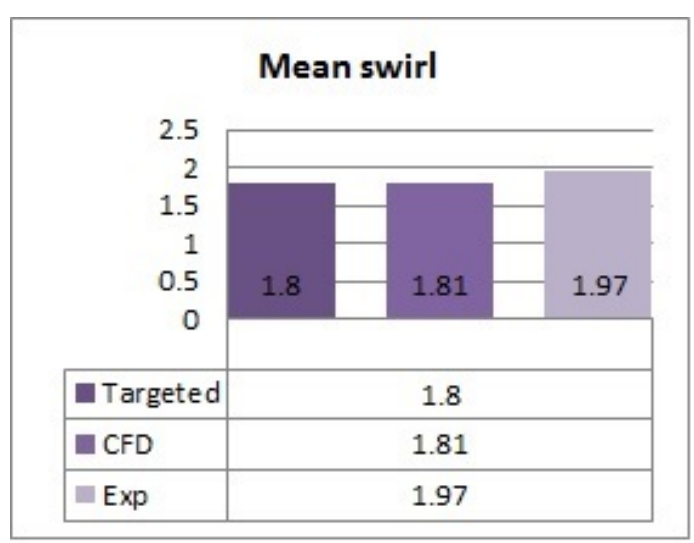

Figure 15. Mean swirl

\subsection{Mean Swirl}

The Figure 15 shows comparison of target value of swirl number with the mean swirl as predicted by CFD simulation and that evaluated from swirl test rig.

\section{Conclusion}

The new methodology is used to design the helical inlet port of diesel engine based on parametric study of geometrical parameters. The proposed design is analyzed using CFD software and steady flow bench experiment. A satisfactory correlation is obtained between experimental and CFD result. The obtained swirl ratio of designed helical port is near to target value. The parametric study result highlighted that, the swirl ratio increases with a decreasing $\mathrm{T} / \mathrm{R}$ value, as there is a correlation between the swirl ratio and the throat height $\mathrm{T}$. In the case of lower $T / R$, it is seen that many streamlines of the incoming air follow the cylinder wall and generate strong swirl. On the other hand with higher $\mathrm{T} / \mathrm{R}$ ratio, a larger proportion of the streamlines are directed toward the center of the cylinder resulting in smaller swirl ratio.

\section{Acknowledgements}

The authors would like to thank all the authorities in department of Power Train Engineering (PTE), The Automotive Research Association of India (ARAI), Pune for providing the facilities and expertise during the course of this work.

\section{References}

[1] Kheyrollahi J., Keshavarz M., Jazayeri S., and Pourfallah M., "Optimization of Intake port shape in a DI DieselEngine Using CFD Flow Simulation”, Conseil International Des Machines a Combustion (CIMAC)Congress 2010, Bergen, Paper no.: 306.

[2] Kulkarni, Y., Mone, M., Desai, A., Markandeya, S., Nayak, N., Aghav, Y., Sohi, N. and Dani, A., "Optimization of Inlet Port Performance on Emission Compliance of Naturally Aspirated DI Diesel Engine”, SAE paper 2005-26-010, 2005.

[3] Shuisheng, J. and Siwei, Z., "Parameter Analysis of Diesel Helical Intake Port Numerical Design”, Energy Procedia, (16). 2012. 558-563.

[4] Eugene, V. and Carsten, O., "Multi-Objective Adjoint Optimization of Intake Port Geometry”, SAE paper 2012-01-0905, 2012.

[5] Mandloi, P. and Verma G., "Design Optimization of an InCylinder Engine Intake Port”, Nafems World Congress, 2009.

[6] Zuelch, S., Behnk, K., Roland D., Bernd F. and Seidel, T., “A New Hardware-Assisted Intake Port Development Process for Diesel Engines Using Doppler Global Velocimetry”, SAE paper 2005-01-0640, 2005.

[7] Kim, H., Yoon, S., Xie X. and Lai M., "Effects of Injection Timings and Intake Port Flow Control on the In-Cylinder Wetted Fuel Footprints during PFI Engine Startup Process”, SAE paper 2005-01-2082, 2005.

[8] Sadakane, S., Sugiyama, M., Kishi, H., Abe, S., Harada, J. and Sonoda, T., "Development of a New V-6 High Performance Stoichiometric Gasoline Direct Injection Engine”, SAE paper 2005-01-1152, 2005.

[9] Heywood J. B., Internal combustion engine fundamentals, McGraw-Hill, Inc., USA, 1988.

[10] McCracken, M. E., and Abrahan, J., "Swirl Spray Interactions in a Diesel Engine”, SAE paper 2001-01-0996, 2001.

[11] Thien, G. E., Description of Measuring Methods for the Investigation of Stationary Flow Properties at Valve Ports and Statements for the Evaluation of the Measurement Results, $A V L$ FA report no. 128/ General/011.

[12] Kawashima, J., Ogawa, H. and Tsuru, Y., "Research on a Variable Swirl Intake Port for 4-Valve High-Speed DI Diesel Engines", SAE paper 982680, 1998.

[13] AVL-FIRE manual. 